\title{
A Mission Statement Does Not a Mission Make: A Mixed Methods Investigation in Public Education
}

\author{
David Coker ${ }^{1}$ \\ ${ }^{1}$ Advanced Education Program, Fort Hays State University, Hays, Kansas, USA \\ Correspondence: David Coker, Advanced Education Department, Fort Hays State University, Hays, Kansas, USA. \\ E-mail: dccoker@fhsu.edu
}

Received: August 23, 2021

Accepted: October 24, 2021

Online Published: January 26, 2022

doi:10.5539/ies.v15n1p210

URL: https://doi.org/10.5539/ies.v15n1p210

\begin{abstract}
Public schools widely use mission statements, and many educational administration programs teach mission statements as a necessary lever for school improvement. A mixed methods investigation examined three levels. An experiential phenomenological analysis examined graduate students' experiences with mission statements within their own schools and professional life. A thematic analysis examined 80 schools in the Midwestern United States, broken down by high and low performance on state academic testing, ecological differences, quantitative structures of the mission statement, and qualitative themes and dimensions. A meta-synthesis compared findings with previous research. There were structural differences in mission statements, but the conclusion was mission statements were a legacy practice which served the political spectacle, and practitioners adopted the practice out of conformity. There was no direct evidence mission statements achieved the stated purpose. Recommendations were made to refashion mission statements and the school improvement process around four factors.
\end{abstract}

Keywords: mission statement, strategic leadership, educational policy, mixed methods, thematic analysis

\section{Introduction}

Students in educational administration graduate programs have long been expected to develop a mission and vision statement for their organization as a rite of passage. Since the 1970s, Drucker's (2011) admonition to answer five questions around what is the mission and Robert Townsend's (1970) Up the Organization: How to Stop the Corporation from Stifling People and Strangling Profits have been at the center of school and organizational improvement efforts. Organizational research suggested mission statements produce a small, positive effect (David et al., 2014).

There were three broad goals of the current study after a literature review. First, there was an examination using an experiential phenomenological approach of the lived experience of school employees and their understanding of mission statements. Secondly, ecological factors and themes related to the structural differences of mission statements in high and low performing schools were explored with thematic analysis using qualitative and quantitative methods. Third, a meta-synthesis compared current findings with research over the past 30 years. A discussion follows, with recommendations on how to operationalize and improve mission statements and strategic leadership within the public schools.

\section{Literature Review}

Many studies called for a mission statement which was lived (Parsons \& Beauchamp, 2012), but past research has not been so kind, finding a tenuous connection between mission statements and organizational success (Markides \& Papadakis, 1998). Mission statement research has not been limited to the United States, with other countries exploring mission statements, divergences, and correlates of effectiveness (Al-Ani \& Ismail, 2015; Kooli, 2019; Zandstra, 2012). How one can prove a mission statement causes anything remains esoteric and ill-defined in most all studies, as there were many ecological factors not described.

Correlational analysis seemed to be enough proof for inferences of causation. Mission statements served instrumental and expressive functions (Pandey et al., 2017), while others found the mission statement influenced employees and improved directionality (Taiwo et al., 2016). Macedo et al. (2016) questioned the slavish adherence to mission statement effectiveness, stating organizational commitment might be a mediating variable. 
There should be an irony, as mission statements were about developing organizational commitment, so the value remains elusive.

Other researchers found a divergence from the orthodoxy. Desmidt and Prinzie (2009) found a lack of empirical evidence to make claims about the efficacy of mission statements. Out of several characteristics, mission, vision, and goals might not be that important (Leithwood \& Azah, 2017). Despite either contrary or elusive evidence, the value of mission statements as a net positive or in need of a slight modification continued in most circles (David et al., 2014; Kadhium et al., 2021; Sidhu, 2003; Turhan \& Kirkgöz, 2020).

There were several recommendations for process-oriented mission statements. Claims were made about including stakeholders and developing commitment as a prerequisite to ensure mission statements were powerful and enduring (Williams et al., 2014). If mission statements failed, the reason was because leaders failed to adopt the correct policies and utilized poor implementation techniques (Herman \& Renz, 1998). Possibly equal weighting of management effectiveness and program effectiveness would produce mission statements which matter (Sowa et al., 2004). Alegre et al. (2018) decried the lack of evidentiary basis of mission statements, but scholars and researchers (Baetz \& Bart, 1996; Darling-Hammond et al., 2007; Desmidt et al., 2011; Rey \& Bastons, 2018) claimed mission statements have a direct connection to organizational success, often with a litany of recipes to further improve any shortcomings.

Mission statements were lauded for providing direction, unity, ethics, and communicating values (Bayrak, 2020; Bowen, 2018; Sun \& Leithwood, 2015). School leadership programs implore starting with goals and a vision (Sammons, 2005; Skaalvik, 2020), and even when shortcomings were found, there was the assumption changes in utilization could make mission statements valuable and necessary (Braun et al., 2012). There was a gap in comparing ecological factors of schools with mission statements. Most studies operated off the assumption mission statements must be valuable and were a necessity without regard to other factors.

\section{Methodology}

There were three primary research questions: What do practitioners know and think about mission statements within their organizations? How do low and high performing schools differ by student and organizational level variables? What differences, if any, exist in mission statements between low performing and high performing schools? All three questions were exploratory in nature and formed the direction of the research within the broader confines of the research paradigms.

A mixed methods research study explored three areas. The relationship of mission statements to what graduate students working in education found about mission statement implementation within the public schools was explored using an experiential phenomenological approach. Next, 80 schools in Illinois, USA, were selected based upon state rankings on academic tests for 2019-2020 for the top 40 schools and the bottom 40 schools, and there was a comparison of school district metrics. A thematic analysis using qualitative and quantitative methods examined mission statements for low and high performing schools. Finally, a meta-synthesis placed the current results into the context of historical findings. The experiential phenomenological study will be presented first, followed by the ecological and thematic analyses of mission statements by school achievement.

\section{Experiential Phenomenological Study}

The importance of knowing if practitioners know and live mission statements predominate the literature, with the necessity "a good thing" (Bardwell, 2008, p. 30). An experiential phenomenological approach was chosen as the method, as the worldview of practitioners would give insight into the meaning of mission statements in one's everyday life (Chenail, 2011; Eddles-Hirsch, 2015; Errasti-Ibarrondo et al., 2018). The essence of what mission statements meant to practitioners was captured, with attention to bracketing and epoche throughout the data analysis (Chan et al., 2013; Moustakas, 1994).

A deductive phenomenological plan guided the process: description of the sample, data collection, data analysis, and reporting. The data sources were an archival collection of assignments in a graduate class of education for strategic management over a two-year period. Microsoft Excel and Microsoft Word were used to analyze the data. Each data file was downloaded and copied into one document. Data analysis began with a first reading with annotations, coding with horizontalism (in vivo, descriptive, and individual/affective), secondary coding and categorization, and a third cycle of conceptualization and interpretation. Reflexivity was practiced by checking before and throughout, with memoing used to explore reflexivity through auditing and reconciliation with the primary sources. As superordinate and subordinate categories were developed, there was a constant return to the original data to account for divergence and stubs (Coker, 2021). Everything was put into a narrative with thick descriptions to give a unified, unobstructed picture of the phenomena and a recounting of bracketing and the 
epoche surrounding the researcher.

The sample comprised 15 students in a post-graduate education specialist program at a state university. All students included worked in the public schools as teachers or administrators across the US. Experience varied from 10 years to 30 years plus. There were 12 females and 3 males. Over a period of two years, students completed an assignment which asked each student to survey five staff members in their school building to see if the mission statement was known. Students also presented the mission statement and answered what they thought was the value of the mission statement and what they would do differently. An archival review of student essays comprised the data source. Anonymity and confidentiality were the primary concern, so all personal information and descriptors were removed and numerical codes were given to each participant used to tag the location of codes. Any student who worked at the university level or in private industry was excluded.

\subsection{Results of Experiential Phenomenological Study}

There were two dimensions to the phenomenological study: a small collection of quantitative data and the qualitative study proper. There were 15 mission statements analyzed by students. The average length was 29.88 words (range 7-53). Each student asked five staff members if the mission statement was known. Most students found practitioners in their school buildings did not know the mission statement $(M=1.25$; range $0-5)$. There was a monotonic relationship between the length of the mission statement and the number of staff members who knew it. Then each student presented analysis of what they found and their views.

The entire story of the value and utility of the mission statement could be a subsequent chapter in Jean Auel's The Clan of the Cave Bear. Three major themes existed: the known-unknown axis, an ingrained sense of meaning and value of mission statements, and mission statements as precondition for success. Each factor coalesced around a coherent idea of mission statements was something which always was and will always be rooted in the lives of the participants and their organizations.

The known-unknown axis meant whether one could recount the mission statement or not, there was a subterranean understanding borne of instinctual directionality. Within each clan of schools, writing on the cave wall did not matter. Most everyone could substitute the values and beliefs through approximation. Common throughout the narratives were comments such as X6 stating "surprised no one knew it . . [the mission statement] improves growth" and X13 stating while no one knew the mission statement, "the overall message was present in the individuals." What was unspoken lived in the hearts and souls of the participants and bound together everyone as they collected around the symbolic fire.

Mission statements were rooted in the primordial and were considered sacrosanct. No cave drawings as a visible reminder were necessary. There could be chants in each cave which sounded eerily similar. A catechism could be written, up there with how to hunt wooly mammoth included in the habitus of the mission statement. Everyone deemed the mission statement important such as X15: "well practiced and important" and X8 finding mission statement necessary, "When I took my graduate courses in Educational Administration." No one could imagine a time when mission statements did not roam the land at the top of the food chain.

There was an esprit de corps amongst all participants within each school. A mission statement was part of the organizational oxygen as much as in The Clan of the Cave Bear each person knew their role and could not deviate. There was no deviation, and the lack of knowledge of the mission statement did not mean the mission statement was not honored and passed on to all who came in contact with each participant. As X9 stated, "the vision ... perfectly aligns" and X2 found "the mission statement is valid and effective." Within the dark, deep depths of each individual, the mission statement sprung up organizational lifeblood which was the root of everyone's success.

There were some divergences in thought. A couple of participants pointed out the organization must have hired people who had the values and traits of the mission statement. Some complained about straying or lack of fidelity with the mission statement, but even these participants maintained the faith. Two other stubs existed, with one participant stating turnover caused staff members to not know the mission statement and one lamented students did not know and comprehend the mission statement. The grand song was mission statements were the natural order of life.

Epoche and bracketing were considered with each step and helped to establish credibility and trustworthiness by checking all results with the written words of the participants. Analysis meant making choices, and two thoughts sprung up early on: paradox and mysticism. There seemed to be a paradox, as no one knew the mission statement, yet only organizations with a mission statement could be successful. My thoughts were participants were practicing insularity, by protecting themselves (the known-unknown) and projecting an ingrained, lived 
experience. Otherwise, participants would have to admit they were failures, as they did not know what was deemed a prerequisite for success. Yet, nowhere was paradox or even the making of a paradox listed. Indeed, for the participants, there was no paradox. What I saw as a need for reconciliation did not exist; the mission statement lived on, was valuable, and was an enduring legacy. There was no mysticism or blind allegiance, as everyone rooted their beliefs in a positive self which lived and breathed the mission statement. My refrain was not part of the grand song. Everyone was on a mission regardless of the mission statement. There was a north star in each person's clan.

Alegre et al. (2018) found mission statements must be articulated to be valuable and impact an organization. Knowing a mission statement can make it motivational (Bartkus et al., 2000). Like the current study, other authors found graduate students in educational administration programs did not know the mission statement, and both studies stated there was still a benefit from mission statements (Gurley et al. 2015; Watkins \& McCaw, 2007). Another small study $(N=6)$ in the Philippines found similar results: Though many participants did not know the mission statement of one's school, there was a known-unknown (Ransom \& Vlachopoulos, 2021). The current study deviated because it did not make the unsubstantiated claim unknown mission statements were important and should be taught more. Within existing educational programs, the entire idea of mission statements seemed to be more smoke and mirrors. Whether known or not, similar organizations with similar purposes believed schools were, well, schools.

\section{Mission Statements Analysis}

An examination of 80 school mission statements in Illinois, broken down by high performing and low performing status on academic testing, was conducted using quantitative and qualitative techniques. First, Schooldigger.com was used to locate the top 40 Illinois school districts and the bottom 40 school districts by state test results. A Google search was conducted of each school district to include in a Microsoft Excel database. If a mission statement could not be found, the school district was skipped; because the top 100 and bottom 100 schools were so close, there was little difference in test scores. Two school districts were skipped in the high scores and three school districts in the low scores. Secondly, the Illinois Interactive Report Card website (illinoisreportcard.com) was searched to pull demographic and academic data for ecological analysis. Next, a thematic analysis was conducted using quantitative and qualitative techniques.

Thematic analysis was a technique loosely defined by V. Braun and Clarke (2012) which could be adapted to many kinds of textual and discursive analyses. There were six steps, though the method was operationalized in the following manner. Microsoft Excel, Microsoft Word, and Wordclouds.com were used for the qualitative analysis. Familiarization of the data involved reading and rereading with annotations. High and low schools were dummy coded. An inductive, exploratory framework was used to code the data line by line for actor, actions, and consequences using in vivo, descriptive, and axial codes. Each sample member was coded with a number, and the initial code was used as a geocode to attach all codes to the original sample. Memoing and comparing happened simultaneously. After coding all data, secondary coding happened with the development of dimensions and themes. At this point, tertiary coding checked dimension and theme coherence and the logicality of the structure. A narrative was produced describing the dimensions and themes. Care was taken to not force stubs, as there was not perfect homogeneity within the sample; if new themes or directions emerged, they would be pursued.

Once dimensions and themes were developed, numbers were assigned to each dimension and theme. This numbering allowed the data to be resorted by geocode and qualitative descriptors. Since there was one coder, intra-rater agreement was checked by recoding, reconciliation, and parity checks, as internal coherence was a concern. With over 900 codes, all data were broken down by high and low performing school, checked, and then recoded independently. Discrepancies were resolved so there was consistency and the themes were cohesive. Because the data could be sorted by dimension and theme, a second and third pass through the data helped to build trustworthiness and credibility because each dimension and theme had to produce agreement. External coherence, or the logicality of each theme with each dimension, was also checked. Lastly, a parity check ensured the in vivo codes matched the number of codes per dimension and connected with each geocode.

By using numbers, the statistical program JASP (JASP Team (2020), JASP (Version 0.14.1)[Computer software]) was used for the demographic and academic data as well as comparing high and low schools with frequencies in thematic analysis. Further analysis included contingency tables to check for differences. Correlation, logistic regression, and k-nearest neighbor explored differences in high and low performing schools. Since dimensions and themes were numbered, a qualitative synthesis explored intradimensional disparities within each theme. 


\subsection{Mission Statement Demographic Analysis}

A number of demographic variables were chosen to analyze school districts by high and low achievement. High achieving enrollment $(M=2,326)$ and number of teachers $(M=172)$ were greater than low achieving enrollment $(M=2,133)$ and number of teacher $(M=138)$, though the number of schools in high achieving schools $(M=3.2)$ showed fewer attendance centers than low achieving schools $(M=4.8)$. Two major sections were used to compare high and low achieving schools: student variables and organizational variables. Both descriptive and inferential statistics explored the nature of the two groups and differences between the samples. By examining the baseline of each school and group, further research could be compared beyond the thematic analysis.

The following student level variables were explored by percentage of the total student population: mobility, low income, special education, homeless, English-language learners (ELL), and chronic absenteeism. Student variables were compared by mean, standard deviation, and the Mann-Whitney U Test. The t-test was not used due to deviations from normality and, or homogeneity of variance. As shown in Table 1, the baseline student data revealed very different characteristics for high and low schools on all factors except ELL, with high achieving schools having a more stable population and less poverty.

Table 1. Student factors by percentages for high and low performance schools

\begin{tabular}{lccc}
\hline Variable & Low Academic Schools & High Academic Schools & Mann-Whitney U Test \\
\hline Mobility & $M=12.68(S D=3.66)$ & $M=3.58(S D=2.50)$ & $U=1561(\mathrm{p}=<.001)$ \\
IEP & $M=15.75(S D=4.04)$ & $M=11.65(S D=2.67)$ & $U=1295(\mathrm{p}=<.001)$ \\
EL & $M=10.58(S D=11.30)$ & $M=4.18(S D=5.21)$ & $U=600(\mathrm{p}=.054)$ \\
Homeless & $M=3.15(S D=3.17)$ & $M=0.60(S D=1.67)$ & $U=1436(\mathrm{p}=<.001)$ \\
Chronic Absenteeism & $M=14.98(S D=7.87)$ & $M=4.68(S D=3.61)$ & $U=1489(\mathrm{p}=<.001)$ \\
Low Income & $M=81.10(S D=19.22)$ & $M=8.70(S D=8.58)$ & $U=1599(\mathrm{p}=<.001)$ \\
\hline
\end{tabular}

Note. $\mathrm{EL}=$ English-language Learner; IEP $=$ Individualized Education Program (Special Education); Alpha level $=.05$.

Organizational variables, shown in Table 2, included money spent per student in the thousands, number of teachers with a master's degree or higher, teacher attendance, teacher retention, average teacher pay, and teacher evaluation rate by proficient or exemplary. Low and high performing schools varied on all levels except teacher evaluation. Teacher pay was also a factor of location, as rural districts per student expenditures and teachers' salaries were significantly less. Most every teacher was evaluated as proficient or exemplary for low and high performing schools; a possible cause was teacher shortages in Illinois meant trying to retain every teacher. Schools felt successful with staff members regardless of academic outcomes.

Table 2. Organizational variables by high and low performance schools

\begin{tabular}{lccc}
\hline Variable & Low Academic Schools & High Academic Schools & Mann-Whitney U Test \\
\hline Average $\$$ & $M=14.77(S D=3.32)$ & $M=18.05(S D=6.29)$ & $U=497(\mathrm{p}=.003)$ \\
Master's \% & $M=46.50(S D=17.40)$ & $M=70.78(S D=17.07)$ & $U=247.5(\mathrm{p}=<.001)$ \\
Teacher Att. \% & $M=84.30(S D=10.14)$ & $M=91.63(S D=6.18)$ & $U=442.5(\mathrm{p}=<.001)$ \\
Teacher Ret. \% & $M=78.23(S D=9.56)$ & $M=90.33(S D=4.33)$ & $U=1441(\mathrm{p}=<.001)$ \\
Teacher Pay $\$$ & $M=54,798(S D=11,887)$ & $M=81,078(S D=21,514)$ & $U=1343(\mathrm{p}=<.001)$ \\
Teacher Eval. \% & $M=97.80(S D=4.06)$ & $M=99.35(S D=1.42)$ & $U=902(\mathrm{p}=.248)$ \\
\hline
\end{tabular}

Note. Average $\$=$ Average money in thousands per student; Master's \% = Master's degree or higher; Teacher Att. $\%=$ Teacher attendance; Teacher Ret. $\%=$ Teacher retention; Teacher Pay $\$=$ Teacher pay in US dollars; Teacher Eval. \% = Teacher evaluation proficient/exemplary; Alpha level $=.05$.

Low and high performing schools differed significantly, as shown in Tables 1 and 2. There was not a common baseline between both groups. Mission statements must be considered within the context of students and the organization. The characteristics of students and teachers matter and must be considered, as there was direct evidence variables such as homelessness affect the school environment. Low performing schools served a much more transient population with greater needs than high performing schools under much more difficult conditions. 


\subsection{Mission Statement Quantitative Analysis}

Analysis of mission statements was conducted by word count, actors, actions, and consequences. The word count between low $(M=31.5 ; S D=18.0)$ and high $(M=38.1 ; S D=44.1)$ were comparable to each other $(t(78)=$ $0.872, p=.193)$. There was a range of mission statements as small as three words and as large as 236 words.

Actors were the entities carrying out the mission; either an iteration of the school district or an implied one was the most common. There were 73 actors listed for the low group and 51 for the high group. The number of actors differed statistically $(t(78)=0.575, p=.008)$. Both groups were similar in listing the school district as the actors. Less common terms, mostly by low performing schools, were the school board, faculty, parents or families, and the community. Low schools claimed more entities carried out the mission of the school district.

Actions were coded along two axes, performative and constative. Performative was further delineated by two dimensions: directive and commissive. Directive meant an action was made available, but the receiving party did not have a duty to act. The top examples of directive included provide, prepare, and foster. Commissive required a dual relationship of action on both the giver and the receiver. The top examples of commissive included empower, develop, and educate. Constative was a statement of fact, such as value, aware, and express. High performing schools $(M=1.48)$ had more actions than low performing schools $(M=1.32)$, though the results were not statistically significant $\left(X^{2}(2, N=196)=4.363, p=.113\right)$. Directive was by far the most common for all groups, followed by commissive, with constative being much less frequent.

Consequences presented three broad themes: student success and development in school and across the lifespan, organizational success and excellence, and external relationships and partnerships. Each theme had several dimensions which defined the characteristics of the mission statements. Broadly, the three themes were similarly distributed $\left(X^{2}(2, N=436)=0.767, p=.681\right)$ between low and high performing schools, and though there were more consequences for high versus low, the number was not statistically significant $(t(78)=1.314, p=.193)$. Student success accounted for about $80 \%$ of all consequences for both high and low, about $13-15 \%$ for organizational success, and the remaining in external relationships and partnerships.

Student success and development had five dimensions: academic/cognitive, social, emotional, civic development, and other. Academic or cognitive had subcategories such as learning, lifelong learning, and academic potential. Academic or cognitive was mediated by social and emotional development, and the scheme presumed academic or cognitive would moderate civic development. Social dealt with primarily behavioral expectations and collaboration. Emotional was character, compassion, and self-regulation. Civic development included citizenship and inclusion in the global society. Other was used to not force stubs into categories or dimensions, and had ideas such as make students daring, deepen understanding of life, and look for novel situations. The other seemed to mediate the other dimensions.

Organizational success and excellence had five dimensions: staff quality, financial concerns, leadership, management, and environment. Staff quality and environment were the two most common dimensions for high and low. Staff quality included excellent and knowledgeable staff. Environment revolved around creating a safe, caring environment.

The last theme, external relationships and partnerships, had three dimensions: diversity and inclusion, partnerships, and other. The external themes were under $5 \%$ for both high and low academic schools. Both high and low performing schools had similar dispersion.

The dimensions were compared quantitatively and no statistically significant difference in frequency was found $\left(X^{2}(2, N=436)=19.10, p=.086\right)$. The structure and dimensions, facially, were similar for high and low schools. The data from the themes and the word count were used to explore if there were differences between high and low schools by the factor of word count and number of actors, actions, and consequences.

Correlation delineated by high and low performing schools was used to see what relationship existed among word count and actors, actions, and consequences. Using Pearson's correlation, word count correlated to actions $(r=0.552, p=<.001)$ and consequences $(r=0.905, p=<.001)$, and consequences and actions $(r=0.590, p=$ $<.001)$ correlated. A logistic regression model, shown in Table 3, found the divergence between actors (OR $=$ $0.408)$ and actions $(\mathrm{OR}=1.820)$ significantly predicted low and high performing schools. The other factors were not significant. Nagelkerke $R^{2}$ was 0.268 , with the overall model significant $X^{2}(75)=17.97, p=.001$. 
Table 3. Logistic regression model of mission statement structures

\begin{tabular}{|c|c|c|c|c|c|c|c|c|c|}
\hline & \multirow[b]{2}{*}{ Estimate } & \multirow[b]{2}{*}{ Standard Error } & \multirow[b]{2}{*}{ Odds Ratio } & \multirow[b]{2}{*}{$\mathrm{z}$} & \multicolumn{3}{|c|}{ Wald Test } & \multicolumn{2}{|c|}{$95 \%$ Confidence interval } \\
\hline & & & & & Wald Statistic & $\mathrm{df}$ & $\mathrm{p}$ & Lower bound & Upper bound \\
\hline (Intercept) & -0.157 & 0.672 & 0.855 & -0.233 & 0.054 & 1 & 0.816 & -1.474 & 1.160 \\
\hline Word Count & -0.008 & 0.018 & 0.992 & -0.457 & 0.209 & 1 & 0.647 & -0.042 & 0.026 \\
\hline \#Actors & -0.897 & 0.353 & 0.408 & -2.541 & 6.455 & 1 & 0.011 & -1.590 & -0.205 \\
\hline \#Actions & 0.599 & 0.257 & 1.820 & 2.329 & 5.422 & 1 & 0.020 & 0.095 & 1.103 \\
\hline \#Conseq. & 0.095 & 0.143 & 1.100 & 0.666 & 0.444 & 1 & 0.505 & -0.185 & 0.376 \\
\hline
\end{tabular}

Note. $\mathrm{V} 1=\mathrm{Top} / 0=$ Bot level ' 1 ' coded as class 1 ; \#Conseq. $=$ Number of consequences.

All structural factors were standardized, and a k-nearest neighbor classification was built, as shown in Table 4 . Actors and consequences showed accuracy in predicting if a mission statement was a low or high performing academic school. The correlation, logistic regression, and k-nearest neighbor suggested though the themes quantitatively were similar, the relationship among word count, actors, actions, and consequences differed.

Table 4. K-nearest neighbors' classification

\begin{tabular}{cccccccc}
\hline Nearest neighbors & Weights & Distance & $\mathrm{n}($ Train $)$ & $\mathrm{n}$ (Validation) & $\mathrm{n}($ Test $)$ & Validation Accuracy & Test Accuracy \\
\hline 2 & rectangular & Euclidean & 52 & 12 & 16 & 0.859 & 0.875 \\
\hline
\end{tabular}

Note. The model is optimized with respect to the validation set accuracy.

Structurally, each factor was similar for high and low schools' mission statements. What quantitative analysis had not revealed were the intradimensional characteristics between high and low performing schools. Between factors, there were marked differences by actors, actions, and consequences. Next up, qualitative analysis examined the nature of the themes and dimensions.

\subsection{Mission Statement Thematic Analysis}

A qualitative analysis of mission statements explored the dimensions underlying each theme. More actors were listed for low performing schools, suggesting there was an attempt at diffusion of responsibility. Actions were similar for the themes of performative and constative, with one important distinction. With few exceptions, low performing schools often spoke in the future tense or of future actions (using the helping verb will and the infinitive to become), while high performing schools spoke about present actions and creations. The dimensions of the three themes, student success, organizational excellence, and external forces varied by the focus and frequency.

Within the theme of student success in school and across the lifespan, academic or cognitive had the following dimensions: aesthetics, all children, critical thinking, learning, lifelong leaner, rigor, full potential, and excellence. There were stubs or rarities, such as pride and curiosity. High performing schools had a much greater focus on learning, aesthetics, and critical thinking $(N=54)$ than low performing schools $(N=16)$. The reverse was true for academic excellence, full potential, rigor, and student growth, with low $(N=34)$ much greater than high performing schools $(N=18)$. Low performing schools focused on stating their mission was excellence, while high performing schools looked more at learning and fostering creativity and imagination.

Social and emotional factors were separated as constructs. Social was viewed as relationships while emotional was defined about the self. Topics of social included relationships, collaboration, and mutual respect. High achieving schools $(N=21)$ mentioned behavioral expectations much more than low achieving schools $(N=10)$. A reasonable hypothesis would have been low achieving schools have more discipline issues, yet mission statements did not reflect this dilemma. Developing a safe, productive organizational environment also had little variance between the two. Emotional regulation (e.g., character, caring, compassion, nurturing, and passion) was similar across schools.

Citizenship (and citizen/citizens) was mentioned as many times as the word child. Terms associated included global, impact, engaged, productive, responsible, and successful. Both high and low schools were similar except low schools $(N=7)$ spoke more about being productive than high performing schools $(N=1)$. Global citizenship was the most frequently mentioned for all schools.

External factors and organizational excellence had few divergences. Diversity and partnerships were relatively 
infrequent and similar across all schools. Leadership, management, and fiscal responsibility were infrequent and had similar frequencies for high and low schools. The one major difference was high performing schools $(N=$ 21) mentioned staff quality much more than low performing schools $(N=9)$.

Trustworthiness and credibility were established with reconciliation, intra-rater agreement, parity check, and a meta-synthesis of findings of others. Reconciliation involved recoding previously encoded data by examining keywords and generating new descriptive, categorical, and thematic codes. If a new code did not agree, reconciliation was used to make a decision on where and how to code an entry. By numbering all codes, descriptions had to match. A parity check ensured all geocodes aligned with the original number. A quantitative and qualitative check improved consistency. Finally, as shown in the next section, a meta-synthesis of findings was used for comparison purposes to check if other researchers found similar results.

\subsection{Mission Statement Meta-Synthesis}

There have been many studies on school mission statements over the past thirty years. Many different methodologies and schemes for coding produced disparate results. Studies compared were at the school and district levels and included findings in Canada and across the United States. Where possible, different studies have been synthesized to compare to the current study.

Mission statements, in one study, showed themes and context driven by state and national policies (Ingle et al., 2020), with the possibility a similar conclusion could be drawn here with topics of lifelong learning, staff quality, and social-emotional learning. Gareis (1996) found citizenship to be most important and academics to be fifth, though the present study and most others found academics at the top. The change could be, as Ingle et al. (2020) found, the national push for academic success from No Child Left Behind could have crowded out other themes. Some studies have been difficult to compare, such as Boerema (2006), as the study looked at broad themes of a school's distinctive beliefs and listing of goals and objectives.

Four studies provided enough information for a direct comparison: Weiss and Piderit (1999), Slate et al. (2008), Stemler et al. (2011), and Perfetto et al. (2013). Combined, the entire sample included 1,004 schools in over 10 states, with a 20 year time span. The Perfetto et al. (2013) study is difficult to generalize, as one word ideas were reported as themes; for example, there was the word all, but what or how it was connected to anything else remains elusive. The other studies, as shown in Table 5, show academic learning and citizenship as the most important. Social and emotional learning appear close by as well. Stemler et al. (2011) provided a major divergence, as no other study mentioned integration. Similarly, the current study found staff quality was important. Different coding schemes were used, but there was significant overlap.

Table 5. Comparison of mission study findings

\begin{tabular}{|c|c|c|c|c|c|}
\hline & Weiss \& Piderit & Slate et al. & Stemler et al. & Perfetto et al. & Current Study \\
\hline Year & 1999 & 2008 & 2011 & 2013 & 2021 \\
\hline Location & Michigan & Texas & 10 states & Texas & Illinois \\
\hline Number & 304 & 100 & 421 & 99 & 80 \\
\hline \multicolumn{6}{|c|}{ Themes by Rank Order } \\
\hline 1 & Academic learning & Academic success & Civic development & Students & Academic \\
\hline 2 & Social skills & Social development & Emotional development & Providing & Citizenship \\
\hline 3 & Self-esteem & citizenship & Cognitive development & All & Emotional \\
\hline 4 & Citizenship/life outcomes & Life-long learning & Integrate into local community & Community & Social \\
\hline 5 & Community/parent involvement & Productive & Integrate into global community & Learning & Staff quality \\
\hline 6 & Caring environment & Challenge & Safe and nurturing environment & Academics & Student/Other \\
\hline 7 & Work & Collaborative & Challenging environment & Developing & Environment \\
\hline 8 & Safe environment & Responsible & Social development & Responsible & Diversity \\
\hline 9 & All children can learn & Caring environment & Vocational preparation & Education & Leadership \\
\hline 10 & Positive environment for staff & Safe environment & Physical development & Environment & Partnerships \\
\hline
\end{tabular}

Note. Only the top 10 themes for each study were reported.

Some studies made comparisons of high performing and low performing schools. Kustigan (2013), using Bebell and Stemler's coding scheme, found in a study of 60 schools in Massachusetts that academics was the most often mentioned theme, but high performing districts had a stronger focus on citizenship, while low performing schools focused on vocational. Boerema (2006) found high performing high schools in Canada focused more on 
knowledge construction and refinement than low performing schools, which was similar to findings in the current study. Through time and space, many schools stated similar goals and objectives within the mission statement.

Slate et al. (2008) conducted research very similarly to the present study. Using the findings in Slate et al. (2008), their themes were recoded and concatenated to the present study's scheme to allow for a direct comparison. For the Slate et al. (2008) study, academic success was combined with lifelong, challenge, and opportunity; social development included collaborative; citizenship included productive; emotional included responsible and empower; and safe environment and caring environment became environment. Though Slate et al. (2008) found the intradimensionality of the themes were diverse by high and low performing schools as in the current study, there was much agreement, as shown in Table 6.

Table 6. Comparison of Slate et al. (2008) and current study by high and low performing schools

\begin{tabular}{ccccc}
\hline & Slate-Low & Current-Low & Slate-High & Current-High \\
\hline 1 & Academic Success & Academic & Academic Success & Academic \\
2 & Citizenship & Citizenship & Citizenship & Citizenship \\
3 & Social Development & Emotional & Social Development & Emotional \\
4 & Environment & Environment & Emotional & Social \\
5 & Emotional & Social & Environment & Staff Quality \\
6 & Partnership & Staff Quality & Partnership & Student/Other \\
7 & Commitment & Student/Other* & Commitment & Environment \\
8 & Physical Development & Partnership* & Physical Development & Diversity \\
9 & & Diversity* & & Leadership \\
10 & & Leadership & & Partnerships \\
\hline
\end{tabular}

Note. Slate et al. (2008) themes were concatenated to follow the current study's themes; Ties signified by *.

Comparisons of studies over the past thirty years suggested mission statements have been relatively stable, with some local differences. Like the coding scheme in Schafft and Biddle (2013) of 480 schools in Pennsylvania, student outcomes, school-society relations, and school environment predominate, even if expressed differently as student factors, organizational variables, and external relations, as in the present study. The meta-synthesis lends further credence to the findings and suggests credibility and trustworthiness while also showing changes over time.

\section{Discussion}

The review of the literature and the meta-synthesis revealed several important differences with the present study. First, other studies did not consider ecological factors. The lack of a baseline for all schools meant assigning causality to a mission statement failed to consider the contextual elements. Organizational characteristics do not develop and act in isolation, and there was no coherent research which suggested changing one element can have a domino effect. Secondly, the present study examined mission statements by actors, actions, and consequences, producing a far different quantitative and qualitative analysis than previous research. Lastly, combined with the explication of the lived experiences around mission statements of practitioners, one finds mission statements were paper relics which were largely unknown.

School improvement methods, which include mission statements as a starting point, were a circus with well-defined shows and acts. There were necessary attractions, such as a vision and mission statement, SMART goals and objectives, stakeholders and focus groups with impressive names, and a fancy binding with fancy paper. All the goodies of idealism must be included, and the process repeats year after year. Repressive desublimation (Brown, 2018), where staff members and stakeholders believe they were moving the system but in reality propagated the status quo, was a key commandment. Insularity from owning failure, idealism, and stakeholder disarmament, was the major results in most every school improvement plan. Little changed except the political and the process; progress and product remained stuck in the past, even if new names and titles sprung up.

Mission statements within graduate schools of education and professional development programs were legacies which symbolized a rite of passage. School improvement experts have taught mission statements so long, no one remembers why and no one can make even a causal connection to research. Incoming classes of prospective educational administration students were giddy at the chance to become a part of a club which makes mission statements. Despite claims of the effectiveness of mission statements (Bartkus et al., 2006; Stemler \& DePascale, 2016; Stemler et al., 2011), the research was neither convincingly nor methodologically rigorous (Desmidt \& 
Prinzie, 2009). There never has been research or evidence which showed two schools with similar ecological variables could adopt another's mission statement and become successful any more than a startup could occupy a global presence by lifting Amazon's mission statement. Mission statements were part of a solutionizing paradigm, of easy, quick fixes which could be adopted uniformly while overlooking important structural changes (Schmoker, 2004).

One saw little unity or improvement, from both a practitioner perspective and a research base which often purports to isolate mission statements as a sort of super variable. Then why do mission statements persist and make their way into virtually every public school in the nation? There were at least three reasons. First, mission statements provided a normative experience (Morphew \& Hartley, 2006); since everyone else was doing it, no one wanted to be left out. Secondly, mission statement were a ritualistic expression of expectations (Meacham \& Gaff, 2006), and it was far easier to make a mission statement than create change which produced value. Finally, mission statements served to define and market an organization through the political spectacle.

Edelman stated the political spectacle involved a theatrical presentation with dramaturgy, political actors with leaders, enemies, and allies, an onstage and backstage production, illusion of reality, a disconnect between the means and the end, symbolic language, and the illusion of democratic participation (Edelman, 1988; Miller-Kahn \& Smith, 2001; Winton, 2010). The political spectacle produced a dramatic display with little substantive change (Szolowicz, 2016). As stated by Anderson (2007), the media influenced the political spectacle by creating particular points of views and anxieties. Mission statements served a purpose of unifying organizations around illusions and the grandiose rather than the aims and goals of the organization. Paradoxes and contradictions coexisted seamlessly.

The director was embodied by the school leadership hierarchy. Power might be wielded by the school apparatchik, but the mission statement made power appear diffused through the optics of greatness and excellence. If everyone were responsible, no one was responsible. Standard scripts, from the current study and a meta-synthesis, gave a formula to reproduce in every school regardless of performance. A prominent example, which was given as a warning (DuFour, 2004), could be termed the DuFour effect, where learning for all became the political cry of the day. Masks covered every role, with all children, excellent academics, lifelong potential, and global citizenship in most productions. Most statements were vague and meaningless (Chait, 1979), touching the needs of every group and working for consensus in an appeal to democratic participation. Not knowing if or when a mission was ever accomplished was by purposeful design. One certainty was every organization claimed to command greatness.

Mission statements set the stage by gross oversimplification, a false sense of unity, and grandiose operations and results. Allies abound throughout, with partnerships, such as staff members, parents, and the community writ large. Enemies were money, staffing, standardized testing, and resources. Parents were simultaneously allies and enemies, though nothing negative would ever grace a mission statement. Onstage, there were chants of excellence and inclusivity, while backstage operations worked to destabilize any claims which challenged the status quo. The symbolic language of excellence, full potential, and several other claims created the illusion of democratic participation and everyone and the organization were above average.

Inputs and outputs varied widely, but schools had a shared commonality in purpose. There was a default behavior. Students arrived at school. Teachers taught a prescribed curriculum. The factory flow beat on, moving students through the system, with success either defined or at least accepted by whatever results were procured. If schools did not adopt a political spectacle, there would be a crisis de jure and de facto. Hospitals, private businesses, and service entities could not operate in such a manner, but other organizations do not serve everyone of a certain class (defined by age) at the same time with a well-established state bureaucracy. There was lack of competition, so the Big Lie must go on. Not my kids. Not my teachers. Not my schools. Not my community. There problem was out there; like constituents who believed Congress was dysfunctional except their own congressman, schools operated off the same fanciful notion.

The drama created a condition where everyone seemed to be content within their own school system. To replace a mission statement and the circus with metrics about dilapidated buildings, poor academic results, ineffective teachers and administrators, and unruly classrooms would require ownership and agency in either failure or suboptimal conditions. Staff members served the cast, both onstage and backstage. Not knowing the mission statement, according to staff members, did not mean one did not live it. Lofty language, spurred by national trends and focus groups, added credence to the political spectacle of the problem out there. There was little divergence or disagreement in the process, and even less evidence different statements pushed the direction of a school district versus describing what was already instituted. 
Automaton conformity, where one conformed to societal expectations and illusions over one's own conscience (Fleming, 2011), tied the results, the circus, and the political spectacle together. The public utility of mission statements (Leonard \& Huang, 2014) trumped the lack of evidence-based support (Gareis, 1996). Groupthink predominated the commonality of themes and dimensions, and doublethink meant relevant stakeholders knew in private which cannot be said publicly. Magical thinking flowed from most mission statements. Mission statements were seen as integral as school books and curriculum. In the startling lack of evidence of effectiveness, most schools, graduate programs of education, and school improvement how-to-guides conformed to the expectations an organization could not survive without a mission statement.

\section{Recommendations}

A mission statement does not a mission make. There is value in the mission, but the overgrown mission statements must be refashioned to breathe new life into what originated as a valuable addition to organization planning. Dufour points out all schools have mission statements but little to show for them (Schmoker, 2001). The same could be said for the rest of the circus. Four transformations could radically alter the educational leadership landscape.

Mission statements must be developed at the micro, meso, and macrolevel around the concept of "all for one." The microlevel could be the department, grade, or unit level. The mesolevel is probably the school level. The macrolevel would be at the district level and beyond. Part of the problem for mission statements, especially in large organizations, are they are so distant as to be rendered meaningless within an individual context. The micro and mesomissions could speak more directly to the first-grade teacher compared to the counselor or high school teacher. Everything would have to support the macromission. There would be a back-to-the-basics, as promulgated by Drucker and Townsend, to produce an organization which moves in unison toward the proximal and distal goals.

Without a change in operation, though, splitting mission statements offers little promise. Developing mission statements around simplicity and succinctness should include the process of reification, performative-commissive, and reductionism. There should be a clear focus on dimensionalities which can produce value-added results. Constatives are possible, but constatives generally do not move an organization or people. Making the mission statements level real, attainable, and measurable could change the schooling process.

Most mission statement research suggested mission statements drive organizations. For example, Campbell and Tumin (2021) stated mission statements created a difference in medical school enrollment patterns. There was no mention of the isolation of other ecological factors which would be just as important, if not more, such as values, vision, demographics, programs, and leadership. Just as plausible was a mission statement was a post hoc description of a movement within the organization. Like the previously mentioned Amazon problem, there was no evidence if other schools adopted someone else's mission statement, any tangible change would happen.

After developing visible, actionable, and usable mission statements, there exists a more important step: A development of an organization's commitment to the ideals of the organization, communication and knowledge sharing, culture building, and a focus on accomplishments. All these organizational factors need leadership and trusteeship. One would find mission statements and school improvement plans were generally not known by the members of an organization. Teachers who claimed to have the known-unknown operate as if they were just teachers, on autopilot doing what the profession does. Yet, there were a myriad of more successful schools, so a professional learning community which develops commitment, communicates plans and strategies, and implements a positive culture can move from action to accomplishment. Mission statements are often the byproduct of either the advertisement or fitting to past practices, so there must be change beyond the political. Unity and direction of purpose are deeper than a surface-level mission statement.

Finally, mission statements must be part of a great movement at the classroom, school, district, state, and national level which envisions school improvement plans (SIPs) and strategic leadership as construction projects. Most all schools across the nation have mission statements and SIPS, yet the results produce the political spectacle year after year. The metaphor of construction project honors the original intent of mission statements as but one vehicle to build a valuable, sustained improvement: A focused, well-ordered plan with a productive and positive school leadership, honors the organizational history and priorities, and improves teacher work (Scribner et al., 1999). There should be a manager, a timeline, and regular check-ins to make key performance indicators and objectives by result produce more than activity and first-order change. Many schools go through the motions, producing plans to satisfy bureaucratic requirements over value-added results (Meyers \& VanGronigen, 2019), much the same way most mission statements operate. Instead of acting like a kindergarten class which produces poor reading results has the mission of global citizenship and lifelong learning, the theatre of the 
absurd could be replaced with a mission closer in line to the central goals of each classroom and grade level. The false causality of a good mission statement equals good schools hampers school improvement.

\section{Limitations}

There were some limitations to the present study. A small sample in the school population was used from one state over one time period. The meta-synthesis and research procedures supported the findings and conclusions, but a broader examination might find different themes and dimensions. There should be a broader examination of ecological factors, something not well considered in the exigent literature.

Future recommendations should center on examining mission statements as part of the whole organizational structure. There was no direct evidence a mission statement could be isolated and assigned a weight for any causality. Unity and direction of purpose matter, but what, if any weight can be assigned to a mission statement remained unanswered. Mission statements have been oversold within organizational research, so the value and utility need corrected. Research should look beyond the public schools for possible answers.

\section{Conclusion}

The present study complements and expands previous research. Mission statements were found to be largely unknown by employees, yet employees and organizations were unwavering in their beliefs on unrequited value. There was a commonality in focusing on academic success and other student-level factors. Ecological factors for high and low performing schools were vastly different, but there was an absence of evidence mission statements had any meaningful impact on results, especially with few in an organization even knowing statements which were generally long and hyperbolic.

"However, neither advocates nor skeptics have produced systematic evidence that mission statements help or hurt organizational performance" (Weiss \& Piderit, 1999, p. 194). Mission statement research continues to rely on anecdotal and spurious claims of how their existence with other factors somehow control what happens. Research into effective schools, regardless of mission statement, show strong cultures built on trust, unity of purpose, and communication of clear, value-added goals improve education (Denison \& Mishra, 1995; Hollingsworth et al., 2018). Mission statements could serve an ancillary role, including the promulgation of the political to advertise pride and success in one's local schools, but a sentence by itself shows little promise of moving people and organizations.

\section{References}

Al-Ani, W. T., \& Ismail, O. H. (2015). Can mission predict school performance? The case of basic education in Oman. School Leadership \& Management, 35(5), 459-476. https://doi.org/10.1080/13632434.2015.1070822

Alegre, I., Berbegal-Mirabent, J., Guerrero, A., \& Mas-Machuca, M. (2018). The real mission of the mission statement: A systematic review of the literature. Journal of Management and Organization, 24(4), 456-473. https://doi.org/10.1017/jmo.2017.82

Anderson, G. L. (2007). Media's impact on educational policies and practices: Political spectacle and social control. Peabody Journal of Education, 82(1), 103-120. https://doi.org/10.1080/01619560709336538

Baetz, M. C., \& Bart, C. K. (1996). Developing mission statements which work. Long Range Planning, 29(4), 526-533. https://doi.org/10.1016/0024-6301(96)00044-1

Bardwell, R. (2008). Transformational assessment: A simplified model of strategic planning. AASA Journal of Scholarship and Practice, 5(2), 30-37. Retrieved from https://www.aasa.org/

Bart, C. K., \& Baetz, M. C. (1998). The relationship between mission statements and firm performance: An $\begin{array}{lllll}\text { exploratory study. Journal of Management Studies, 35(6), 823-853. } & \text {. }\end{array}$ https://doi.org/10.1111/1467-6486.00121

Bartkus, B., Glassman, M., \& McAfee, B. (2006). Mission statement quality and financial performance. European Management Journal, 24(1), 86-94. https://doi.org/10.1016/j.emj.2005.12.010

Bartkus, B., Glassman, M., \& McAfee, R. B. (2000). Mission statements: are they smoke and mirrors? Business Horizons, 43(6), 23. https://doi.org/10.1016/S0007-6813(00)80018-X

Bayrak, T. (2020). A content analysis of top-ranked universities' mission statements from five global regions. $\begin{array}{lllll}\text { International Journal of Educational Development, } & 72, & 102130 .\end{array}$ https://doi.org/10.1016/j.jedudev.2019.102130

Boerema, A. J. (2006). An analysis of private school mission statements. Peabody Journal of Education, 81(1), 180-202. https://doi.org/10.1207/S15327930pje81018 
Bowen, S. A. (2018). Mission and vision. The international encyclopedia of strategic communication, 1-9. https://doi.org/10.1002/9781119010722.iesc0111

Braun, S., Wesche, J. S., Frey, D., Weisweiler, S., \& Peus, C. (2012). Effectiveness of mission statements in organizations-a review. Journal of Management \& Organization, 18(4), 430-444. https://doi.org/10.5172/jmo.2012.18.4.430

Braun, V., \& Clarke, V. (2012). Thematic analysis. In H. Cooper, P. M. Camic, D. L. Long, A. T. Panter, D. Rindskopf, \& K. J. Sher (Eds.), APA handbooks in psychology ${ }^{\circledR}$. APA handbook of research methods in psychology, Vol. 2. Research designs: Quantitative, qualitative, neuropsychological, and biological (pp. 57-71). American Psychological Association.

Brown, W. (2018). Neoliberalism's Frankenstein: Authoritarian freedom in twenty-first century "democracies." Critical Times, 1(1), 60-79. https://doi.org/10.1215/26410478-1.1.60

Campbell, K. M., \& Tumin, D. (2021). Mission matters: Association between a medical school's mission and minority student representation. Plos One, 16(2), e0247154. https://doi.org/10.1371/journal.pone.0247154

Chait, R. (1979). Mission madness strikes our colleges. Chronicle of Higher Education, 18, 36. Retrieved from https://www.chronicle.com/

Chan, Z. C., Fung, Y. L., \& Chien, W. T. (2013). Bracketing in phenomenology: Only undertaken in the data collection and analysis process. The Qualitative Report, 18(30), 1-9. Retrieved from http://citeseerx.ist.psu.edu/

Chenail, R. J. (2011). Ten steps for conceptualizing and conducting qualitative research studies in a pragmatically curious manner. The Qualitative Report, 16(6), 1715-1732. Retrieved from https://nsuworks.nova.edu/tqr/vol16/iss6/13

Coker, D. C. (2021). Making thematic analysis systematic: The seven deadly sins. Journal of Studies in Education, 11(3), 126-146. https://doi.org/10.5296/jse.v11i3.18882

Darling-Hammond, L., LaPointe, M., Meyerson, D., Orr, M. T., \& Cohen, C. (2007). Preparing school leaders for a changing world: Lessons from exemplary leadership development programs. School Leadership Study. Final Report. Stanford Educational Leadership Institute. Retrieved from https://edpolicy.stanford.edu/

David, M. E., David, F. R., \& David, F. R. (2014). Mission statement theory and practice: A content analysis and new direction. International Journal of Business, Marketing, \& Decision Science, 7(1), 95-110. Retrieved from http://citeseerx.ist.psu.edu/

Denison, D. R., \& Mishra, A. K. (1995). Toward a theory of organizational culture and effectiveness. Organization Science, 6(2), 204-223. https://doi.org/10.1287/orsc.6.2.204

Desmidt, S., \& Prinzie, A. (2009). Does your mission statement have any value? An explorative analysis of the effectiveness of mission statements from a communication perspective (No. 09/568). Ghent University, Faculty of Economics and Business Administration. https://doi.org/10.5465/ambpp.2009.44257947

Desmidt, S., Prinzie, A., \& Decramer, A. (2011). Looking for the value of mission statements: A meta-analysis of 20 years of research. Management Decision, 49(3), 468-483. https://doi.org/10.1108/00251741111120806

Drucker, P. F. (2011). The five most important questions you will ever ask about your organization (Vol. 90). John Wiley \& Sons.

DuFour, R. (2004). What is a "professional learning community"? Educational Leadership, 61(8), 6-11. Retrieved from http://www.ascd.org/publications/educational-leadership/

Eddles-Hirsch, K. (2015). Phenomenology and educational research. International Journal of Advanced Research, 3(8), 251-260 Retrieved from http://www.journalijar.com/

Edelman, M. (1988). Constructing the political spectacle. University of Chicago Press.

Errasti-Ibarrondo, B., Jordán, J. A., Díez-Del-Corral, M. P., \& Arantzamendi, M. (2018). Conducting phenomenological research: Rationalizing the methods and rigour of the phenomenology of practice. Journal of Advanced Nursing, 74(7), 1723-1734. https://doi.org/10.1111/jan.13569

Fleming, T. (2012). Fromm and Habermas: Allies for adult education and democracy. Studies in Philosophy and Education, 31(2), 123-136. https://doi.org/10.1007/s11217-011-9268-1

Gareis, C. R. (1996). The characteristics and degrees of de facto consensus concerning the mission of K-12 public education in Virginia (Unpublished doctoral dissertation). The College of William and Mary. 
Gurley, D. K., Peters, G. B., Collins, L., \& Fifolt, M. (2015). Mission, vision, values, and goals: An exploration of key organizational statements and daily practice in schools. Journal of Educational Change, 16(2), 217-242. https://doi.org/10.1007/s10833-014-9229-x

Herman, R. D., \& Renz, D. O. (1998). Nonprofit organizational effectiveness: Contrasts between especially effective and less effective organizations. Nonprofit Management and Leadership, 9(1), 23-38. https://doi.org/10.1002/nml.9102

Hollingworth, L., Olsen, D., Asikin-Garmager, A., \& Winn, K. M. (2018). Initiating conversations and opening doors: How principals establish a positive building culture to sustain school improvement efforts. Educational Management Administration \& Leadership, 46(6), 1014-1034. https://doi.org/10.1177/1741143217720461

Ingle, W. K., Greenwell, T., \& Woods, J. (2020). Commonplace and common language: Kentucky's district mission statements. Journal of Educational Administration, 58(3), 321-340. https://doi.org/10.1108/JEA-09-2019-0158

Kadhium, V. S., Betteg, S., Sharma, P., \& Nalliah, R. P. (2021). Do mission statements matter? An evaluation of dental school mission statements. Journal of Dentistry and Oral Science, 3(1), 1-9. https://doi.org/10.37191/Mapsci-2582-3736-3(1)-074

Kooli, C. (2019). Governing and managing higher education institutions: The quality audit contributions. Evaluation and Program Planning, 77, 101713. https://doi.org/10.1016/j.evalprogplan.2019.101713

Kustigian, B. M. (2013). Mission driven educational leadership--does it matter? Examining the correlations between district mission and student achievement (Unpublished doctoral dissertation). University of Massachusetts at Amherst. Retrieved from https://scholarworks.umass.edu/open_access_dissertations/749/

Leithwood, K., \& Azah, V. N. (2017). Characteristics of high-performing school districts. Leadership and Policy in Schools, 16(1), 27-53. https://doi.org/10.1080/15700763.2016.1197282

Leonard, W. P., \& Huang, C. H. (2014). Linking classroom performance to the institutional mission statement. SAGE Open, 4(1). https://doi.org/10.1177/2158244013518056

Macedo, I. M., Pinho, J. C., \& Silva, A. M. (2016). Revisiting the link between mission statements and organizational performance in the non-profit sector: The mediating effect of organizational commitment. European Management Journal, 34(1), 36-46. https://doi.org/10.1016/j.emj.2015.10.003

Markides, C., \& Papadakis, V. M. (1998). What constitutes an effective mission statement: An empirical investigation. New managerial mindsets: Organizational transformation and strategy implementation. John Wiley \& Sons.

Meacham, J., \& Gaff, J. G. (2006). Learning goals in mission statements: Implications for educational leadership. Liberal Education, 92(1), 6-13. Retrieved from http://www.aacu.org/publications/index.cfm

Meyers, C. V., \& VanGronigen, B. A. (2019). A lack of authentic school improvement plan development: Evidence of principal satisficing behavior. Journal of Educational Administration, 57(3), 261-278. https://doi.org/10.1108/JEA-09-2018-0154

Miller-Kahn, L., \& Smith, M. L. (2001). School choice policies in the political spectacle. Education Policy Analysis Archives, 9, 50. https://doi.org/10.14507/epaa.v9n50.2001

Morphew, C. C., \& Hartley, M. (2006). Mission statements: A thematic analysis of rhetoric across institutional type. The Journal of Higher Education, 77(3), 456-471. https://doi.org/10.1080/00221546.2006.11778934

Moustakas, C. (1994). Phenomenological research methods. Sage Publications. https://doi.org/10.4135/9781412995658

Pandey, S., Kim, M., \& Pandey, S. K. (2017). Do mission statements matter for nonprofit performance? Insights from a study of US performing arts organizations. Nonprofit Management and Leadership, 27(3), 389-410. https://doi.org/10.1002/nml.21257

Parsons, J., \& Beauchamp, L. (2012). Leadership in effective elementary schools: A synthesis of five case studies. US-China Education Review, 8, 697-711. Retrieved from http://www.davidpublisher.org/Home/Journal/UCER-A

Perfetto, J. C., Holland, G., Davis, R., \& Fedynich, L. V. (2013). A comparison of mission statements of national blue ribbon schools and unacceptable Texas high schools. Journal of College Teaching \& Learning (TLC), 
10(4), 289-294. https://doi.org/10.19030/tlc.v10i4.8125

Ransom, B., \& Vlachopoulos, D. (2021). The meaning of mission statements to school practice and professional development: An interpretative phenomenological analysis. Educar, 57(1), 49-63. https://doi.org/10.5565/rev/educar.1126

Rey, C., \& Bastons, M. (2018). Three dimensions of effective mission implementation. Long Range Planning, 51(4), 580-585. https://doi.org/10.1016/j.lrp.2017.07.002

Sammons, P. (1995). Key characteristics of effective schools: A review of school effectiveness research. B \& MBC Distribution Services.

Schafft, K. A., \& Biddle, C. (2013). Place and purpose in public education: School district mission statements and educational (dis) embeddedness. American Journal of Education, 120(1), 055-076. https://doi.org/10.1086/673173

Schmoker, M. (2004). Tipping point: From feckless reform to substantive instructional improvement. Phi Delta Kappan, 85(6), 424-432. https://doi.org/10.1177/003172170408500605

Schmoker, M. J. (2001). The results fieldbook: Practical strategies from dramatically improved schools. ASCD.

Scribner, J. P., Cockrell, K. S., Cockrell, D. H., \& Valentine, J. W. (1999). Creating professional communities in schools through organizational learning: An evaluation of a school improvement process. Educational Administration Quarterly, 35(1), 130-160. https://doi.org/10.1177/0013161X99351007

Sidhu, J. (2003). Mission statements: Is it time to shelve them? European Management Journal, 21(4), 439-446. https://doi.org/10.1016/S0263-2373(03)00072-0

Skaalvik, C. (2020). School principal self-efficacy for instructional leadership: Relations with engagement, emotional exhaustion and motivation to quit. Social Psychology of Education, 23, 479-498. https://doi.org/10.1007/s11218-020-09544-4

Slate, J. R., Jones, C. H., Wiesman, K., Alexander, J., \& Saenz, T. (2008). School mission statements and school performance: A mixed research investigation. New Horizons in Education, 56(2), 17-27. Retrieved from http://www.cpe.ied.edu.hk/newhorizon

Sowa, J. E., Selden, S. C., \& Sandfort, J. R. (2004). No longer unmeasurable? A multidimensional integrated model of nonprofit organizational effectiveness. Nonprofit and Voluntary Sector Quarterly, 33(4), 711-728. https://doi.org/10.1177/0899764004269146

Stemler, S. E., \& DePascale, M. (2016). Aligning mission and measurement. In Psychosocial skills and school systems in the 21st century (pp. 57-92). Springer. https://doi.org/10.1007/978-3-319-28606-8_3

Stemler, S. E., Bebell, D., \& Sonnabend, L. A. (2011). Using school mission statements for reflection and $\begin{array}{llll}\text { research. Educational } & \text { Administration }\end{array}$ https://doi.org/10.1177/0013161X10387590

Sun, J., \& Leithwood, K. (2015). Direction-setting school leadership practices: A meta-analytical review of evidence about their influence. School Effectiveness and School Improvement, 26(4), 499-523. https://doi.org/10.1080/09243453.2015.1005106

Szolowicz, M. A. (2016). Putting political spectacle to work: Understanding local resistance to the Common Core. Education Policy Analysis Archives, 24, 114. https://doi.org/10.14507/epaa.24.2521

Taiwo, A. A., Lawal, F. A., \& Agwu, P. E. (2016). Vision and mission in organization: Myth or heuristic device? The International Journal of Business \& Management, 4(3). Retrieved from www.theijbm.com/

Toh, S. Y., Cheok, J., \& Mughal, S. A. (2019). Reciprocal fit concept in mission statement research. In 2019 13th International Conference on Mathematics, Actuarial Science, Computer Science and Statistics (MACS) (pp. 1-4). IEEE. https://doi.org/10.1109/MACS48846.2019.9024790

Townsend, R. (1970). Up the organization: How to stop the corporation from stifling people and strangling profits. Jossey-Bass.

Turhan, B., \& Kirkgöz, Y. (2020). An analysis on mission statements of Turkish primary schools: Similarities and differences. Research in Educational Administration and Leadership (REAL), 5(1), 71-98. https://doi.org/10.30828/real/2020.1.3

Watkins, S. G., \& McCaw, D. S. (2007). Analysis of graduate students' knowledge of school district mission, vision, and core values. In National Forum of Educational Administration and Supervision Journal, 24(3), 
71-91. Retrieved from http://www.nationalforum.com/Journals/NFEASJ/NFEASJ.htm

Weiss, J. A., \& Piderit, S. K. (1999). The value of mission statements in public agencies. Journal of Public Administration Research and Theory, 9(2), 193-224. https://doi.org/10.1093/oxfordjournals.jpart.a024408

Williams, R. I. Jr., Morrell, D. L., \& Mullane, J. V. (2014). Reinvigorating the mission statement through top management commitment. Management Decision, 52(3), 446-459. https://doi.org/10.1108/MD-10-2012-0736

Winton, S. (2010). Character education, new media, and political spectacle. Journal of Education Policy, 25(3), 349-367. https://doi.org/10.1080/02680931003624532

Zandstra, A. M. (2012). Mission statements of Christian elementary schools in the United States and the Netherlands. Journal of Research on Christian Education, 21(2), 116-131. https://doi.org/10.1080/10656219.2012.698827

\section{Copyrights}

Copyright for this article is retained by the author(s), with first publication rights granted to the journal.

This is an open-access article distributed under the terms and conditions of the Creative Commons Attribution license (http://creativecommons.org/licenses/by/4.0/). 